\title{
IMPLEMENTASI NILAI-NILAI PANCASILA SEBAGAI PENDUKUNG TUMBUH KEMBANG WAWASAN KEBANGSAAN PADA MATA PELAJARAN PPKn DI SMP NEGERI 7 PALEMBANG
}

\author{
Rahma Danniarti \\ Guru SMP Negeri 7 Palembang \\ e-mail: rahmadanniarti28@gmail.com
}

\begin{abstract}
This study aimed at describing the implementation of Pancasila as the values which supported the improvement and development of national insight on PPKn subject in SMP Negeri 7 of Palembang. This research was a descriptive research using qualitative approach. It was conducted in SMP Negeri 7 Palembang involving the teachers and the students as the object of the research. The data were collected through observation, interviews, and documentation. The validity of the data was measured through triangulation technique. The results showed that students in SMP Negeri 7 began to show the attitude of nationalism, such as: respect for the dignity of human beings as the creation of the Almighty God by reading the holy verses of the Qur'an and Dhuha prayer at zero hour (06:40); helped a needy friend, dared to respond to what the teacher had taught. From this study, it is clear that Pancasila is really the foundation and the principal of life of the Indonesian nation. Through Pancasila and PPKn subject, the education in Indonesia is hoped to be able to create the generation whose attitudes and actions really reflect the identity of the Indonesian nation which is based on the values of Pancasila. It is also taught abou how to defend the country. If one region in Indonesia is threatened then the threat applies to all Indonesian citizens.
\end{abstract}

Keywords: The Value of Pancasila, National Insight, PPKn Subject

PENDAHULUAN

Indonesia sebagai negara yang berdaulat memiliki wilayah yang sangat luas. Jumlah penduduknya yang besar dari beragam etnis dengan tradisi yang berbeda dan aneka adat istiadat, menambah kekayaan nusantara, keragaman budaya dan adat istiadat menjadi ciri khas perbedaan itu. Juga keragaman keyakinan dan agama pun menambah mozaik keindahan bumi nusantara. Nilai-nilai nasionalisme yang terkandung dalam konsep Negara Kesatuan Republik Indonesia (NKRI), Pancasila, UUD 1945 dan Bhinneka Tunggal Ika menjadi bingkai persatuan dan kesatuan. Dalam perjalanannya bingkai tersebut menemui jalan terjal dan kerikil serta ancaman yang dapat mengoyaknya. Perlu upaya serius untuk menjaga bingkai persatuan dan kesatuan itu dari pengaruh ideologi (radikalisme) yang mengancam baik dari dalam maupun luar negeri. Penguatan nilai-nilai Pancasila sebagai bingkai persatuan dan kesatuan di implementasi pada mata pelajaran Pendidikan Pancasila dan Kewarganegaraan (PPKn) dalam rangka tumbuh kembang wawasan kebangsaan (Nuhrison M.Nuh, dkk, : 2015).

Dari pengalaman sejarah, sejak Budi Utomo 1908 yang kita peringati sebagai Hari 
Kebangkitan Nasional dan Ikrar Sumpah yang tidak hapal Pancasila. Karena timbulnya Pemuda 1928, Proklamasi Kemerdekaan hal-hal tersebut membuat penulis 1945 sampai dengan saat ini, kita telah mengadakan penelitian di SMP Negeri 7 mengalami pasang surut dan dinamika dalam Palembang.

kehidupan berbangsa dan bernegara. Saat ini Kecenderungan semakin memudarnya kita telah masuk pada era globalisasi, Wawasan Kebangsaan tercermin dari perilaku transparansi dan reformasi yang sedang hidup yang semakin memprihatinkan. menguji keberadaan bangsa Indonesia, tanpa Sentimen dan fanatisme suku, ras dan disadari keadaan tersebut telah mampu antargolongan semakin menonjol sehingga menggeser nilai-nilai bangsa yang selama ini seringkali rentan terhadap terjadinya gesekanterpatri kuat dan menjiwai kehidupan gesekan dan konfflik bernuansa SARA bermasyarakat, berbangsa, dan bernegara. diberbagai daerah. Kondisi tersebut Nilai-nilai kebangsaan yang terkandung diperparah oleh perbuatan sebagian kelompok dalam Pancasila tidak lagi menjadi bagian masyarakat yang secara sadar menjual yang harus dimengerti, dipahami dan bangsanya sendiri kepada bangsa asing diamalkan dalam kehidupan bermasyarakat. dengan menguasai isu-isu HAM, Sebaliknya telah menjurus kearah kehidupan Demokratisasi dan lingkungan hidup untuk individualistik dan materialistik yang kepentingan bangsa yang lebih besar. Sulit mengakibatkan semakin jauh dari nilai-nilai rasanya bagi bangsa Indonesia untuk kembali jati diri, kepribadian dan keimanan bangsa bangkit dari keterpurukan saat ini ditengah Indonesia.

deras masuknya faham asing yang

Siswa SMP Negeri 7 Palembang pada pergaulan sehari-hari dilingkungan sekolah sudah menunjukkan hal-hal tersebut, yaitu individualistik, kepribadian dan keimanan semakin jauh. Contohnya: siswa banyak yang tidak bisa sholat dan mengaji; tidak peduli kalau melihat temannya sedang mengalami kesulitan dan kesusahan, malahan mereka senang melihat hal itu; tidak peduli dengan kebersihan lingkungan, kurang sopan kalau berbicara dengan guru dan teman; banyak bertentangan dengan paham Pancasila sehingga ancaman terjadinya disintegrasi bangsa tanpa disadari telah mengancam sendi-sendi kehidupan bangsa Indonesia.

Rasa kebangsaan warga negara Indonesia saat ini hanya muncul bila ada suatu faktor pendorong, seperti kasus pengklaiman beberapa kebudayaan dan pulau-pulau kecil Indonesia seperti Sipadan, Ligitan, serta Ambalat oleh Malaysia beberapa waktu yang lalu. Namun rasa 
kebangsaan itu kembali berkurang seiring kebangsaan anak bangsa tersebut. Padahal dengan meredanya konflik tersebut.

kita masih mampu dan dapat mengatasi

Pada kasus GAM, jarang dari permasalahan-permasalahan yang terjadi di masyarakat Indonesia yang bersedia menjadi dalam negeri. Baik masalah Poso, masalah sukarelawan untuk membantu menumpas Aceh, masalah Ambon, masalah Papua dan pemberontakan GAM. Tetapi manakala masalah lainnya di Indonesia ini.

rakyat Irak diserang oleh Amerika Serikat, Begitu juga masyarakat dalam banyak orang menangis dan mengumpulkan menyampaikan aspirasinya terlihat betapa dana serta menjadi relawan untuk membantu lunturnya nilai-nilai luhur bangsa ini yang rakyat Irak. Namun, ketika rakyat Aceh tercermin baik dalam orasinya, disakiti, disiksa, diperas dan dibunuh oleh spanduk/poster yang dibentangkan maupun GAM, tidak terlihat adanya kelompok orang tingkah laku yang tidak santun. Pernah terjadi menangis dan berusaha untuk menjadi pada suatu peristiwa demonstrasi, mereka relawan dalam membantu menyelesaikan menginjak-injak dan membakar gambar/foto masalah Aceh. Hal tersebut merupakan presiden yang nota bene sebagai lambang cerminan betapa lunturnya rasa kebangsaan negara dan harus dihormati oleh seluruh anak yang dimiliki bangsa ini. bangsa.

Sebagai perbandingan, dahulu kala Perilaku lain yang sangat ketika presiden Soekarno mencanangkan mengkuatirkan generasi tua atau para prang Trikora untuk membebaskan Irian Barat dari tua adalah adanya kebiasaan atau budaya tangan penjajah Belanda, orang berbondong- yang banyak melanggar norma-norma agama bondong mendaftarkan diri untuk menjadi dan sosial pada generasi muda. Pergaulan sukarelawan dalam mengusir Belanda dari bebas, seks pranikah, penggunaan narkoba Irian Barat. Hal ini sangat ironis sekali adalah sebagian contoh yang dapat dilihat dengan kondisi saat ini. dari lingkungan generasi muda kita saat ini.

Hal ini ironis dengan fenomena yang Dengan memudarnya rasa kebangsaan ada di negra kita saat ini dimana anak bangsa dapat mengancam dan menghancurkan yang meminta adanya campur tangan pasukan bangsa Indonesia. Hal ini terjadi karena nilaidari negara asing untuk mengatasi masalah nilai Pancasila sebagai tumbuh kembang dalam negeri baik di Poso maupun di Maluku. wawasan kebangsaan menjadi lemah dan Peristiwa tersebut menunjukkan betapa dapat dengan mudah ditembus oleh pihak rendahnya rasa nasionalisme atau semangat luar. Sekarang bukan dijajah dalam bentuk 
fisik, namun dijajah secara mental dan nilai-nilai Pancasila terutama paham ideologi.

kebangsaan; (2) tidak terlaksananya

Banyak sekali kebudayaan dan paham pemahaman terhadap nilai-nilai Pancasila barat yang masuk ke dalam bangsa Indonesia terutama rasa kebangsaan; (3) tidak yang berpengaruh negatif dapat dengan terlaksananya pemahaman terhadap nilai-nilai mudah masuk dan diterima oleh bangsa Pancasila terutama semangat kebangsaan. Indonesia. Dengan terjadinya hal itu, maka

Kesadaran bangsa Indonesia tentang akan terjadi akulturasi, bahkan Pancasila, Kewarganegaraan, serta Wawasan menghilangnya kebudayaan dan kepribadian Kebangsaan sangat rendah. Hal ini dapat kita bangsa yang seharusnya menjadi jati diri lihat dalam kehidupan sehari-hari. Misalnya, bangsa. banyak terjadi konflik antargolongan,

Dalam aspek perekonomian negara, demonstrasi anarkhis, dan pelanggaran Hak dengan memudarnya rasa kebangsaan Asasi Manusia. Sehingga kesadaran bangsa mengakibatkan perekonomian bangsa Indonesia mengenai hal tersebut ditumbuhkan Indonesia jauh tertinggal dari negara-negara melalui mata pelajaran Pendidikan Pancasila tertangga. Saat ini masyarakat hanya dan Kewarganegaraan yang diajarkan sejak memikirkan apa yang negara berikan untuk tingkat dasar sampai perguruan tinggi.

mereka, bukan memikirkan apa yang mereka Revolusi mental harus dimulai dari dapat berikan pada negara. Dengan keegoisan pendidikan, mengingat peran pendidikan inilah, masyarakat lebih menuntut hak sangat strategis dalam membentuk mental daripada kewajibannya sebagai warga negara. anak bangsa. Pengembangan kebudayaan Sikap individual yang lebih mementingkan maupun karakter bangsa diwujudkan melalui diri sendiri dan hanya memperkaya diri ranah pendidikan. Menurut Suprapto (2014) sendiri tanpa memberikan kontribusi pada pendidikan pengembangan karakter adalah negara, mengakibatkan perekonomian negara sebuah proses berkelanjutan dan tidak pernah semakin lemah. berakhir (never ending process). Selama

Melihat perkembangan Wawasan sebuah bangsa ada dan ingin tetap eksis, Kebangsaan yang dimiliki komponen bangsa pendidikan karakter harus menjadi bagian saat ini, apabila dibiarkan dapat dipastikan terpadu dari pendidikan alih generasi NKRI yang sangat kita cintai ini akan (Kristiawan, 2016).

berimplikasi terhadap hal-hal sebagai berikut: Mata pelajaran Pendidikan Pancasila (1) tidak terlaksananya pemahaman terhadap dan Kewarganegaraan (PPKn) merupakan 
salah satu muatan kurikulum Pendidikan Wawancara merupakan percakapan dengan Dasar dan Menengah sebagaimana maksud tertentu. Percakapan itu dilakukan diamanatkan dalam Pasal 2, Pasal 3, dan oleh dua pihak, yaitu pewawancara Pasal 37 Undang-Undang Nomor 20 Tahun (interviewer) yang mengajukan pertanyaan 2003 tentang Sistem Pendidikan Nasional dan dan yang diwawancarai yang memberikan Penjelasan Pasal 37 “...dimaksudkan untuk jawaban atas pertanyaan itu (Moleong, membentuk siswa menjadi manusia yang 2007:135). Wawancara digunakan untuk memiliki rasa kebangsaan dan cinta tanah menjaring data atau informasi yang berkaitan air”. Berdasarkan rumusan tersebut, telah dengan pengaruh nilai-nilai Pancasila yang di dikembangkan Mata pelajaran Pendidikan integrasikan dalam mata pelajaran PPKn Pancasila dan Kewarganegaraan (PPKn) yang sebagai pendukung tumbuh kembang diharapkan dapat menjadi wahana edukatif wawasan kebangsaan.

dalam mengembangkan siswa menjadi Observasi yang digunakan untuk manusia yang memiliki rasa kebangsaan dan menggali data dari sumber data yang berupa cinta tanah air yang dijiwai oleh nilai-nilai peristiwa, tempat atau lokasi dan benda serta Pancasila, Undang Undang Dasar Negara rekaman gambar (Sutopo, 2002: 64). Republik Indonesia Tahun 1945, semangat Observasi dilakukan untuk melihat muatan Bhinneka Tunggal Ika dan komitmen Negara materi nilai-nilai Pancasila pada mata Kesatuan Republik Indonesia. pelajaran PPKn sebagai pendukung tumbuh kembang wawasan kebangsaan.

\section{METODE PENELITIAN}

Dokumentasi digunakan

untuk

Penelitian ini merupakan penelitian memperoleh data. Studi dokumen dilakukan deskriptif dengan menggunakan pendekatan untuk memperoleh data tentang implementasi kualitatif. Penelitian ini bertujuan untuk nilai-nilai Pancasila sebagai pendukung mendeskripsikan bagaimana implementasi tumbuh kembang wawasan kebangsaan pada nilai-nilai Pancasila sebagai pendukung mata pelajaran PPKn.

tumbuh kembang wawasan kebangsaan pada Keabsahan data yang digunakan adalah mata pelajaran PPKn di SMP Negeri 7 teknik triangulasi. triangulasi sebagai teknik Palembang. pengumpulan data yang bersifat

Teknik pengumpulan data yang menggabungkan dari berbagai teknik digunakan dalam penelitian ini adalah pengumpulan data dan sumber data yang wawancara, observasi, dan dokumentasi. telah ada. Bila peneliti melakukan 
pengumpulan data dengan triangulasi, maka maka dengan otomotis bangsa Indonesia akan sebenarnya peneliti mengumpulkan data yang kehilangan jati dirinya. Sehingga bangsa sekaligus menguji kredibilitas data. Pengujian Indonesia dengan mudah dipengaruhi oleh itu dilakukan dengan mengecek kredibilitas budaya-budaya bangsa lain yang belum tentu data dengan berbagai teknik pengumpulan sesuai untuk diterapkan. Dalam hal ini data dan sumber data (Sugiyono, 2007: 83). Pancasila berperan untuk mem-filter atau

\section{HASIL PENELITIAN DAN}

\section{PEMBAHASAN}

Bangsa Indonesia adalah bangsa yang terdiri dari bermacam-macam suku, adat, diperbolehkan masuk ke dalam wilayah serta budaya. Dari keragaman inilah muncul Indonesia dengan tidak meninggalkan adanya semboyan "Bhinneka Tunggal Ika" kebudayaan asli Indonesia yang telah ada yang artinya "Berbeda-beda namun tetap satu sejak dahulu dan dikembangkan oleh warga jua". Semboyan inilah yang menjadi alat Indonesia.

pemersatu bangsa Indonesia. Bukan hanya Warga Negara Indonesia adalah suku, adat serta budaya saja yang berbeda. sekumpulan orang yang menempati wilayah Namun, karakteristik manusia dan pola Indonesia dan harus tunduk dan patuh pada pemikirannya sangat jauh berbeda antara satu aturan serta norma-norma yang berlaku. orang atau satu wilayah dengan lainnya. Oleh Warga Negara Indonesia mempunyai hak dan karena itu dibutuhkan suatu pendidikan yang kewajiban. Hak dan kewajiban tersebut harus dapat menumbuhkan sikap kebangsaan antar dilaksanakan secara seimbang karena akan warga negara Indonesia, sehingga tidak lagi mempengaruhi kelangsungan hidup mereka ditemukan adanya perpecahan-perpecahan dalam berbangsa dan bernegara. Hal ini perlu yang akan mengakibatkan lunturnya diajarkan kepada setiap Warga Negara persatuan dan kesatuan bangsa Indonesia. Indonesia sejak usia dini melalui Pendidikan

Bangsa Indonesia adalah bangsa yang Pancasila dan Kewarganegaraan (PPKn) agar berideologi Pancasila yang merupakan suatu mereka dapat mengetahu, memahami dan tujuan dan identitas bangsa. Sila-sila dalam mengaplikasikannya dalam kehidupan sehariPancasila mengandung makna yang sangat hari. Bukan hanya tentang hak dan kewajiban luas. Makna-makna ini jika tidak dikaji dan saja yang diajarkan. Namun, juga meliputi diajarkan kepada generasi penerus bangsa wawasan kebangsaan (Santoso: 2005). 
Menurut Kristiawan (2015) Indonesia penyelenggaraan negara Indonesia needs a great quantity and quality of human (Kemendikbud, 2016). resources as the main supporter of the Pancasila berisi lima sila yang development (Ikhsan, 2014). Large hakikatnya berisi lima nilai dasar yang population is the most important for the fundamental. Nilai-nilai Pancasila tersebut progress and setbacks of a nation depends on adalah sebagai berikut :

human factors. The problems of politic, 1. Nilai Ketuhanan economic, social can also be completed by human resources. However, to solve the problems and deal with the high civilization competition become more advanced, Indonesia needs revitalization and strengthening strong character of human resources. One aspect that can be done to prepare for the strong human character is through education (Suprapto, 2014). Education is the only key that can achieve strong human resources (Suyatno, 2010).

Pancasila sebagai dasar negara dan 2 pandangan hidup bangsa terdapat kandungan akan nilai-nilai. Pancasila sebagai dasar negara dan ideologi nasional adalah nilai-nilai yang bersifat tetap. Namun, pada penjabarannya dilakukan secara dinamis dan kreatif yang sesuai dengan kebutuhan perkembangan masyarakat Indonesia. Diterimanya Pancasila sebagai dasar negara dan ideologi nasional (pandangan hidup bangsa) membawa dampak bahwa nilai-nilai Pancasila dijadikan landasan pokok, dan landasan fundamental bagi setiap
Nilai Ketuhanan mengandung arti adanya pengakuan dan keyakinan bangsa Indonesia terhadap adanya Tuhan sebagai pencipta alam semesta. Nilai ini menyatakan bangsa Indonesia adalah bangsa yang religius bukan bangsa yang ateis. Contoh nilai Ketuhanan: saling menghormati dan toleransi antara pemeluk agama yang berbeda-beda: kebebasan menjalankan ibadah sesuai dengan agama dan kepercayaan-Nya.

\section{Nilai Kemanusiaan}

Nilai Kemanusiaan mengandung arti kesadaran sikap dan perilaku yang sesuai dengan nilai-nilai moral dalam hidup bersama atas dasar tuntutan hati nurani dengan memperlakukan sesuatu hal sebagaimana mestinya, dan adanya pengakuan terhadap hak asasi manusia. Contoh nilai Kemanusiaan: pengakuan terhadap adanya harkat dan martabat manusia; mengembangkan sikap tenggang rasa agar tidak berbuat semenamena terhadap orang lain.

\section{Nilai Persatuan}


Volume 2, No. 2, Juli-Desember 2017

Nilai Persatuan Indonesia

batiniah. Keadilan adalah nilai yang amat mengandung makna usaha ke arah bersatu dalam kebulatan atau kesadaran rakyat untuk membina rasa nasionalisme dalam Negara Kesatuan Republik Indonesia. Kesadaran bersatu itu tercipta dengan baik jika sungguh-sungguh menghayati semboyan Bhinneka Tunggal mendasar yang diharapkan oleh seluruh bangsa. Contoh nilai Keadilan: bersikap adil dan suka memberi pertolongan kepada orang lain; cinta akan kemajuan dan pembangunan bangsa baik material maupun spiritual.

Kelima nilai-nilai Pancasila dijabarkan Ika. Contoh nilai Persatuan: memiliki dalam berbagai peraturan perundangan, rasa cinta tanah aor dan bangsa serta rela ketetapan, keputusan, kebijakan pemerintah, berkorban untuk kepentingan bangsa dan program-program pembangunan dan negara; pengakuan terhadap keragaman peraturan-peraturan. Penjabaran nilai-nilai itu suku bangsa dan budaya bangsa yang disebut nilai instrumental. Hal ini disebabkan sekaligus mendorong ke arah pembinaan nilai-nilai dasar dari Pancasila merupakan persatuan dan kesatuan bangsa. satu kesatuan yang saling berhubungan dan

4. Nilai Kerakyatan menjiwai satu sama lain. Selain itu, semua

Nilai Kerakyatan mengandung makna nilai dasar dari sila-sila Pancasila tersebut suatu pemerintahan dari rakyat, oleh harus menjadi acuan dalam penyelenggaraan rakyat, dan untuk rakyat dengan cara bernegara.

musyawarah mufakat melalui lembaga- Bangsa Indonesia adalah bangsa yang lembaga perwakilan. Nilai ini menganut dipandang dari aspek sosial budaya adalah paham demokrasi. Contoh nilai bangsa yang beragam yang dari segi Kerakyatan: mengutamakan musyawarah kewilayahannya bercorak nusantara, sehingga dalam setiap mengambil keputusan; kita memandang sebagai satu kesatuan yang mengutamakan kepentingan negara dan utuh. Dalam GBHN telah disebutkan bahwa masyarakat daripada kepentingan pribadi hakikat Wawasan Kebangsaan diwujudkan atau golongan.

dengan menyatakan kepulauan nusantara

5. Nilai Keadilan sebagai satu kesatuan politik, ekonomi, sosial

Nilai Keadilan mengandung makna budaya, dan pertahanan keamanan. Selain itu sebagai dasar sekaligus tujuan, yaitu dapat disebutkan pula bahwa hakikat tercapainya masyarakat Indonesia yang Wawasan Kebangsaan adalah keutuhan adil dan makmur secara lahiriah ataupun bangsa dan kesatuan wilayah nasional. 
Menurut Suhady dan Sinaga (2006),

Dorongan yang melahirkan kebangsaan Wawasan kebangsaan dapat diartikan sebagai kita bersumber dari perjuangan untuk sudut pandang/cara memandang yang mewujudkan kemerdekaan, memulihkan mengadung kemampuan seseorang atau martabat kita sebagai manusia. Wawasan kelompok orang untuk memahami kebangsaan Indonesia menolak segala keberadaan jati diri sebagai suatu bangsa diskriminasi suku, ras, asal-usul, keturunan, dalam memandang dirinya dan bertingkah warna kulit, kedaerahan, golongan, agama laku sesuai falsafah hidup bangsa dalam dan kepercayaan kepada Tuhan Yang Maha lingkungan internal dan lingkungan eksternal. Esa, kedudukan maupun status sosial. Konsep

Gubernur Lemhannas RI, mengatakan kebangsaan kita bertujuan membangun dan bahwa wawasan kebangsaan adalah cara mengembangkan persatuan dan kesatuan.

pandang bangsa Indonesia mengenai diri dan Wawasan kebangsaan Indonesia tidak lingkungannya, mengutamakan kesatuan dan mengenal adanya warga negara kelas satu, persatuan wilayah dalam penyelenggaraan kelas dua, mayoritas atau minoritas. Hal ini kehidupan bermasyarakat, berbangsa dan dibuktikan dengan tidak dipergunakannya bernegara. Kesatuan atau integrasi nasional bahasa Jawa misalnya sebagai bahasa bersifat kultural dan tidak hanya bernuansa nasional tetapi justru bahasa melayu yang struktural tetapi mengandung satu kesatuan kemudian berkembang menjaadi bahasa ideologi, kesatuan politik, kesatuan ekonomi, Indonesia.

kesatuan sosial budaya, dan kesatuan Wawasan kebangsaan mengandung tiga pertahanan keamanan (Lemhannas: 1994). unsur dasar, yaitu wadah (contour), isi

Konsep kebangsaan merupakan hal (content), dan tata laku (conduct). Wadah yang sangat mendasar bagi bangsa Indonesia. (contour) meliputi seluruh wilayah Indonesia Dalam kenyataannya konsep kebangsaan itu yang memiliki sifat serba nusantara dengan telah dijadikan dasar negara dan ideologi kekayaan alam dan penduduk serta aneka nasional yang tercantum di dalam Pancasila ragam budaya. Bangsa Indonesia memiliki sebagaimana terdapat dalam Pembukaan sebuah organisasi kenegaraan yang UUD NRI Tahun 1945 Alinea keempat. merupakan wadah berbagai kegiatan Konsep kebangsaan itulah yang membedakan kenegaraan dalam wujud supra struktur bangsa Indonesia dengan bangsa-bangsa lain politik, sedangkan wadah kehidupan di dunia ini. bermasyarakat adalah berbagai kelembagaan dalam wujud infra struktur politik. 
Isi (content) adalah aspirasi bangsa otonomi daerah harus dapat mencegah yang berkembang di masyarakat dan cita-cita disintegrasi/pemecahan negara kesatuan, serta tujuan nasional yang terdapat dalam mencegah merongrong wibawa pemerintah Pembukan UUD NRI Tahun 1945. Untuk pusat, mencegah timbulnya pertentangan mencapainya bangsa Indonesia harus mampu antara pemerintah pusat dengan pemerintah menciptakan persatuan dan kesatuan dalam daerah. Melalui upaya tersebut diharapkan keragaman yang ada pada Indonesia. dapat terwujud pemerintah pusat yang bersih

Tata laku (conduct) merupakan hasil dan akuntabel dan pemerintah daerah yang interaksi antara wadah dan isi yang terdiri tumbuh dan berkemabng secara mandiri dari tata laku batiniah dan lahiriah. Tata laku dengan daya saing yang sehat antar daerah batiniah mencerminkan jiwa, semangat, dan dengan terwujudnya kesatuan ekonomi, mentalitas yang baik dari bangsa Indonesia. kokohnya kesatuan politik, berkembangnya Tata laku lahiriah tercermin dalam tindakan, kesatuan budaya yang memerlukan warga perbuatan, dan perilaku. bangsa yang kompak dan bersatu dengan ciri

Menurut Winarno (2007), tujuan kebangsaan, netralitas birokrasi pemerintahan wawasan kebangsaan dibedakan menjadi yang berwawasan kebangsaan, sistem tujuan ke dalam dan tujuan ke luar. Tujuan ke pendidikan yang menghasilkan keder dalam yaitu menjamin perwujudan persatuan pembangunan berwawasan kebangsaan.

dan kesatuan segenap aspek kehidupan Wawasan Kebangsaan merupakan nasional yaitu politik, ekonomi, sosial prinsip yang sangat fundamental bagi bangsa budaya, dan pertahanan keamanan. Indonesia dalam mencegah terjadinya Sedangkan tujuan ke luar yaitu terjaminnya disuntegrasi bangsa. Hal ini sesuai dengan kepentingan nasional dalam dunia yang serba teori Ernest Renan yang mengatakan bahwa berubah dan ikut serta melaksanakan kebangsaan merupakan suatu kesatuan ketertiban dunia berdasarkan kemerdekaan, solidaritas, kesatuan yang terdiri dari orangperdamaian abadi dan keadilan sosial serta orang saling merasa setia kawan antara satu mengembangkan suatu kerja sama dan saling sama lain. Kebangsaan tidak dapat disamakan menghormati. dengan yang didasarkan atas kesamaan ras,

Wawasan kebangsaan Indonesia yang bahasa, agama, kepentingan bersama, menjadi sumber perumusan kebijakan geografi atau batas-batas alamiah permukaan desentralisasi pemerintahan dan bumi. Oleh karena itu, diperlukan kerja sama pembangunan dalam rangka pengembangan yang bersinergi antara instansi satu dengan 
yang lainnya untuk mewujudkan tujuan memberikan potensi sumber daya yang besar bersama, sehingga perpecahan dapat dihindari bagi peningkatan kesejateraan rakyat, seminimal mungkin. Hal ini sejalan dengan menghasilkan cara pendang tentang keutuhan teori sinergitas yang apabila dengan kerja wilayah nusantara yang perlu dipertahankan sama yang tinggi dan saling mempercayai oleh bangsa Indonesia, serta sebagai sarana akan menghasilkan pola komunikasi yang integrasi Nasional.

bersifat sinergitas yang bearti kerja sama Menurut Depdiknas (2003) mata yang terjalin akan menghasilkan keluaran pelajaran Pendidikan Pancasila dan yang lebih besar dari penjumlahan hasil Kewarganegaraan merupakan mata pelajaran keluaran masing-masing pihak atau manfaat penyempurnaan dari mata pelajaran yang lebih baik.

Pendidikan Kewarganegaraan (PKn) yang

Wawasan kebangsaan bagi bangsa dikenal dalam Kurikulum 2006. Indonesia memiliki makna: (1) wawasan Penyempurnaan tersebut dilakukan atas dasar kebangsaan mengamanatkan kepada seluruh pertimbangan: (1) Pancasila sebagai dasar bangsa agar menempatkan persatuan, negara dan pandangan hidup bangsa kesatuan, serta kepentingan dan keselamatan diperankan dan dimaknai sebagai entitas inti bangsa dan negara di atas kepentingan pribadi yang menjadi sumber rujukan dan kriteria atau golongan; (2) wawasan kebangsaan keberhasilan pencapaian tingkat kompetensi mengembangkan persatuan Indonesia dan pengorganisasian dari keseluruhan ruang sedemikan rupa sehingga asas Bhinneka lingkup mata pelajaran Pendidikan Pancasila Tunggal Ika dipertahankan; (3) wawasan dan Kewarganegaraan; (2) substansi dan jiwa kebangsaan tidak memberi tempat pada Undang-Undang Dasar Negara Republik patriotisme yang licik; (4) NKRI yang Indonesia Tahun 1945, nilai dan semangat merdeka, bersatu, berdaulat, adil dan makmur Bhinneka Tunggal Ika, dan komitmen Negara bertekad untuk mewujudkan bangsa yang Kesatuan Republik Indonesia yang maju dan mandiri serta sejahtera lahir batin, ditempatkan sebagai bagian integral dari sejajar dengan bangsa lain yang sudah maju. Pendidikan Pancasila dan Kewarganegaraan,

Manfaat yang kita dapatkan dari dan menjadi wahana psikologis-pedagogis konsepsi wawasan kebangsaan adalah pembangunan warganegara Indonesia yang diterima dan diakuinya konsepsi Nusantara di berkarakter Pancasila (Kemendikbud : 2017). forum internasional, pertambahan luas Selain itu, melalui penyempurnaan PKn wilayah sebagai ruang hidup yang menjadi PPKn tersebut terkandung gagasan 
dan harapan untuk menjadikan PPKn sebagai melaksanakan hak-hak dan kewajibannya salah satu mata pelajaran yang mampu untuk menjadi warga negara Indonesia yang memberikan kontribusi serta solusi atas cerdas, terampil, dan berkarakter yang berbagai krisis yang melanda Indonesia, diamanatkan oleh Pancasila dan UUD NRI terutama krisis multidimensional. PPKn Tahun 1945.

sebagai mata pelajaran yang memiliki misi Menurut UU No. 20 Tahun 2003 mengembangkan keadaban Pancasila, indikator keberhasilan sistem pendidikan diharapkan mampu membudayakan dan nasional khususnya Pendidikan Pancasila dan memberdayakan siswa agar menjadi Kewarganegaraan (PPKn) bertujuan untuk warganegara yang cerdas dan baik serta membentuk peserta didik menjadi manusia menjadi pemimpin bangsa dan negara yang memiliki rasa kebangsaan dan cinta Indonesia di masa depan yang amanah, jujur, tanah air. Hal ini diperlukan untuk: (1) cerdas, dan bertanggungjawab. menyatukan tekad menjadi bangsa yang kuat,

Dalam konteks kehidupan global dihormati dan disegani oleh bangsa lain; (2) Pendidikan Pancasila dan Kewarganegaraan mempererat persatuan dan kesatuan, baik selain harus meneguhkan keadaban Pancasila dalam spirit maupun geografi. juga harus membekali siswa untuk hidup Mata pelajaran Pendidikan Pancasila dalam kancah global sebagai warga dunia dan kewarganegaraan dimaksudkan untuk (global citizenship). Oleh karena itu, membentuk siswa menjadi manusia yang substansi dan pembelajaran PPKn perlu memiliki rasa kebangsaan dan cinta tanah air diorientasikan untuk membekali warga negara dalam konteks nilai dan moral Pancasila, Indonesia agar mampu hidup dan kesadaran berkonstitusi Undang-Undang berkontribusi secara optimal sesuai dinamika Dasar Negara Republik Indonesia 1945, nilai kehidupan abad 21. Untuk itu, pembelajaran dan semangat Bhinneka Tunggal Ika, serta PPKn selain mengembangkan nilai dan moral komitmen Negara Kesatuan Republik Pancasila, juga mengembangkan semua visi Indonesia.

dan keterampilan abad ke-21 sebagaimana Secara umum tujuan mata pelajaran telah menjadi komitmen global.

Pendidikan Pancasila dan Kewarganegaraan

Visi misi mata pelajaran Pendidikan pada jenjang Pendidikan Dasar dan Pancasila dan Kewarganegaraan adalah Menengah adalah mengembangkan potensi memfokuskan pada pembentukan warga siswa dalam seluruh dimensi negara yang memahami dan mampu kewarganegaraan, yakni: (1) sikap 
kewarganegaraan termasuk keteguhan, Esa yang hidup bersama dalam berbagai komitmen dan tanggung jawab tatanan sosial kultural.

kewarganegaraan (civic confidence, civic Dengan demikian PPKn lebih memiliki committment, and civic responsibility); (2) kedudukan dan fungsi sebagai berikut: (1) pengetahuan kewarganegaraan (civic PPKn merupakan pendidikan nilai, knowledge); (3) keterampilan moral/karakter, dan kewarganegaraan khas kewarganegaraan termasuk kecakapan dan Indonesia yang tidak sama sebangun dengan partisipasi kewarganegaraan (civic civic education di USA, citizenship education competence and civic responsibility). di $U K$, talimatul muwatanah di negara-negara

Secara khusus Tujuan PPKn yang Timur Tengah, education civicas di Amerika berisikan keseluruhan dimensi tersebut, Latin; (2) PPKn sebagai wahana pendidikan sehingga siswa mampu: (1) menampilkan nilai, moral/karakter Pancasila dan karakter yang mencerminkan penghayatan, pengembangan kapasitas psikososial pemahaman, dan pengamalan nilai dan moral kewarganegaraan Indonesia sangat koheren Pancasila secara personal dan sosial; (2) (runut dan terpadu) dengan komitmen memiliki komitmen konstitusional yang pengembangan watak dan peradaban bangsa ditopang oleh sikap positif dan pemahaman yang bermartabat dan perwujudan warga utuh tentang Undang-Undang Dasar Negara negara yang demokratis dan bertanggung Republik Indonesia Tahun 1945; (3) berpikir jawab sebagaimana termaktub dalam Pasal 3 secara kritis, rasional, dan kreatif serta UU No.20 Tahun 2003.

memiliki semangat kebangsaan dan cinta Ruang lingkup mata pelajaran tanah air yang dijiwai oleh nilai-nilai Pendidikan Pancasila dan Kewarganegaraan Pancasila, Undang Undang Dasar Negara (PPKn), meliputi: (1) Pancasila, sebagai dasar Republik Indonesia Tahun 1945, semangat negara, ideologi nasional, dan pandangan Bhinneka Tunggal Ika, dan komitmen Negara hidup bangsa; (2) Undang-Undang Dasar Kesatuan Republik Indonesia, dan (4) Negara Republik Indonesia Tahun 1945 berpartisipasi secara aktif, cerdas, dan sebagai hukum dasar tertulis yang menjadi bertanggung jawab sebagai anggota landasan konstitusional kehidupan masyarakat, tunas bangsa, dan warga bermasyarakat, berbangsa, dan bernegara; (3) negarasesuai dengan harkat dan martabatnya Negara Kesatuan Republik Indonesia, sebagai sebagai makhluk ciptaan Tuhan Yang Maha kesepakatan final bentuk Negara Republik Indonesia; (4) Bhinneka Tunggal Ika, sebagai 
wujud filosofi kesatuan yang melandasi dan mengalami musibah; menjenguk temannya mewarnai keberagaman kehidupan yang sakit, saling menyayangi dengan bermasyarakat, berbangsa, dan bernegara. temannya, sopan kalau berbicara guru dan

Untuk mengetahui tingkat keberhasilan teman (3) implementasi nilai Persatuan: implementasi nilai-nilai Pancasila sebagai upacara bendera yang dilaksanakan dengan pendukung tumbuh kembang wawasan hikmat; kegiatan pramuka; lomba-lomba kebangsaan pada mata pelajaran Pendidikan waktu class meeting; sudah banyak yang Pancasila dan Kewarganegaraan (PPKn), hapal Pancasila dengan diterapkannya maka perlu ditentukan indikator-indikator membaca Pancasila sebelum pelajaran yang digunakan untuk mengukur keberhasilan dimulai (4) implementasi nilai Kerakyatan: tersebut. Indikator tersebut, antara lain: (1) siswa mempunyai keberanian untuk bertanya penghargaan terhadap harkat dan martabat kepada guru tentang materi yang belum manusia sebagai makhluk ciptaan Tuhan dipahaminya; siswa juga berani untuk Yang Maha Esa; (2) Tekad bersama untuk menanggapi apa yang diajarkan oleh guru (5) berkehidupan kebangsaan yang bebas, implementasi nilai Keadilan: dalam merdeka, dan berdaulat; (3) cinta akan tanah penerimaan siswa baru sesuai dengan air dan bangsa; (4) demokrasi atau kedaulatan persyaratan yang telah ditetapkan rakyat; (5) kesetiakawanan sosial; (6) sebelumnya, bukan karena uang yang lebih masyarakat adil dan makmur. besar dari yang lainnya seseorang siswa itu

Implementasi nilai-nilai Pancasila diterima; di ruang BK setiap siswa yang sebagai pendukung tumbuh kembang bermasalah baik akademik, biaya atau lainnya wawasan kebangsaan pada mata pelajaran boleh meminta bantuan kepada sekolah.

Pendidikan Pancasila dan Kewarganegaraan Hasil penelitian ini didukung oleh hasil (PPKn) di SMP Negeri 7 Palembang sudah penelitian Ahmad dkk (2017) yang terlihat antara lain: (1) implementasi nilai menyebutkan Guru-guru SMA Plus Negeri 2 Ketuhanan: setiap hari pada jam ke-nol Banyuasin III terlibat dalam proses (06.40) siswa membaca ayat suci Al-Quran; pembelajaran, diskusi, dan mengambil setiap pagi siswa mengerjakan sholat dhuha inisiatif sebagai upaya membangun (2) implementasi nilai Kemanusiaan: peduli pendidikan karakter. SMA Plus Negeri 2 kalau melihat temannya sedang mengalami Banyuasin III mengimplementasikan kesulitan dan kesusahan dengan menyumbang pembelajaran karakter adalah melalui ataupun menjenguk temannya yang Pendekatan Holistik, yaitu mengintegrasikan 
perkembangan karakter ke dalam setiap aspek implementasi nilai Keadilan: dalam

kehidupan sekolah.

\section{KESIMPULAN}

Hasil penelitian ini menyebutkan bahwa implementasi nilai-nilai Pancasila sebagai pendukung tumbuh kembang wawasan kebangsaan pada mata pelajaran Pendidikan boleh meminta bantuan kepada sekolah.

Pancasila dan Kewarganegaraan (PPKn) di SMP Negeri 7 Palembang sudah terlihat antara lain: (1) implementasi nilai Ketuhanan: setiap hari pada jam ke-nol (06.40) siswa membaca ayat suci Al-Quran; setiap pagi siswa mengerjakan sholat dhuha implementasi nilai Kemanusiaan: peduli kalau melihat temannya sedang mengalami kesulitan dan kesusahan dengan menyumbang ataupun menjenguk temannya yang mengalami musibah; menjenguk temannya yang sakit, saling menyayangi dengan temannya, sopan kalau berbicara guru dan teman (3) implementasi nilai Persatuan: upacara bendera yang dilaksanakan dengan hikmat; kegiatan pramuka; lomba-lomba waktu class meeting; sudah banyak yang hapal Pancasila dengan diterapkannya membaca Pancasila sebelum pelajaran dimulai (4) implementasi nilai Kerakyatan: siswa mempunyai keberanian untuk bertanya kepada guru tentang materi yang belum dipahaminya; siswa juga berani untuk menanggapi apa yang diajarkan oleh guru (5) penerimaan siswa baru sesuai dengan persyaratan yang telah ditetapkan sebelumnya, bukan karena uang yang lebih besar dari yang lainnya seseorang siswa itu diterima; di ruang BK setiap siswa yang bermasalah baik akademik, biaya atau lainnya

\section{DAFTAR PUSTAKA}

Ahmad, S., Kristiawan, M., Tobari, T., \& Suhono, S. (2017). Desain Pembelajaran SMA Plus Negeri 2 Banyuasin III Berbasis Karakter Di Era Masyarakat Ekonomi ASEAN. Iqra (Educational Journal), 2(2), 403-432.

Depdiknas. (2003). Media pembelajaran. Jakarta: Direktorat Pendidikan Dasar dan Menengah Direktorat Tenaga Kependidikan.

Ikhsan, A. (2014). Construct mental revolution on education. Jambi: Jambiekspres.

http://www.jambiekspres.co.id/berita19248-mengkonstruksi-revolusi-mentaldalam-pendidikan.html

Kementerian Pendidikan dan Kebudayaan Republik Indonesia Edisi Revisi. (2016). Buku Siswa Pendidikan Pancasila dan Kewarganegaraan. Jakarta : Kementerian Pendidikan dan Kebudayaan Republik Indonesia

Kementerian Pendidikan dan Kebudayaan Republik Indonesia. (2017). Inspirasi Pembelajaran dan Penilaian Mata Pelajaran Pendidikan Pancasila dan Kewarganegaraan (PPKn) SMP/MTs. Jakarta: Kementerian Pendidikan dan Kebudayaan Republik Indonesia 
Kristiawan, M. (2015). A Model of Suyatno (2010). Developing cultural Educational Character in High School education and national character. Article Al-Istiqamah Simpang Empat, West Pasaman, West Sumatera. Research Journal of Education, 1(2), 15-20.

Kristiawan, M. (2016). Telaah Revolusi Mental Dan Pendidikan Karakter Dalam Pembentukkan Sumber Daya Manusia Indonesia Yang Pandai dan Berakhlak Winarno. (2007). Paradigma Baru: Mulia. Ta'dib, 18(1), 13-25.

Lemhannas. (1994). Kewiraan Untuk presented on National Forum by Kopertis 3 Jakarta

Undang-Undang No 20 Tahun 2003 tentang Sistem Pendidikan Nasional. Jakarta: CV Tamita Utama

Pendidikan Kewarganegaraan. Bandung: PT. Bumi Aksara

Mahasiswa. Jakarta: PT. Gramedia Pustaka Utama

Moleong, L.J. (2007). Metodologi Penelitian Kualitatif. Bandung: Remaja Rosda Karya

Nuhrison M. Nuh, dkk. (2015). Mereka Membicarakan Wawasan Kebangsaan. Jakarta: Puslitbang Kehidupan Keagamaan Badan Litbang dan Diklat Agama RI

Santoso Budi, dkk. (2005). Pendidikan Kewarganegaraan. Jakarta: Gramedia

Sugiyono. (2007). Memahami Penelitian Kualitatif. Bandung: CV. Alfabeta

Suhady, Idup dan A.M. Sinaga. (2006). Wawasan Kebangsaan Dalam Kerangka NKRI. Jakarta: Lembaga Administrasi Negara-Republik Indonesia

Suprapto (2014). Mental revolution from education. Unika Darma Cendikia: Surabaya:

http://www.jawapos.com/baca/artikel/66 69/revolusi-mental-dimulai-daripendidikan

Sutopo, HB. (2002). Metodologi Penelitian Kualitatif. Surakarta: UNS Press 
JMKSP

Jurnal Manajemen, Kepemimpinan, dan Supervisi 